\title{
Accounting as a management tool for non-industrial private forestry
}

\author{
Akmal S. Hyder ${ }^{\mathrm{a} *}$, Lars Lönnstedt ${ }^{\mathrm{b}}$, Markku Penttinen ${ }^{\mathrm{c}}$

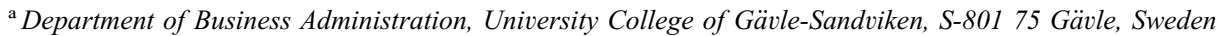 \\ ${ }^{\mathrm{b}}$ Department of Forestry Economics, The Swedish University of Agricultural Sciences, S-901 83 Umeä, Sweden \\ ${ }^{\mathrm{c}}$ Finnish Forest Research Institute, Helsinki Research Centre, Unioninkatu 40A, FIN-00170 Helsinki, Finland
}

Received 1 April 1996; accepted 1 December 1997

\begin{abstract}
Non-industrial private forest owners (NIPF owners) supply most of the roundwood in Scandinavia. For these owners, it is the supply of timber that provides income and return on invested capital. Owners have to decide whether to invest more in their property, or to disinvest. They have to find ways to increase revenue and cut costs. By applying business accounting practices to traditional forest accounting we propose principles for profit and loss accounts and balance sheets for NIPF owners. We argue that it is important for the forest owner to complement the strictly regulated accounting with contingent adjustments. An economic analysis of a medium-sized forest holding illustrates the importance of this type of adjustment. Research on this question can help to increase economic awareness among private owners and to support the harmonization of forestry accounting in the EU. (C) 1999 Elsevier Science Ltd. All rights reserved.
\end{abstract}

Keywords: Financial and cost accounting; Net (or realized) profit of the enterprise; Calculated profit of the property; ROI; Value of the forest

\section{Introduction}

\subsection{Importance of profitability accounting}

Ever since forests have been used for industrial purposes, forestry has been a cyclical business. An example of this and of its implications can be seen as recently as the first half of the 1990s. Between 1990 and 1993 the price for the kraft pulp softwood market was halved. This had a direct effect on the profitability of forestry in exporting

\footnotetext{
*Corresponding author. Tel.: + 46-26-648631; fax: + 46-26-648704; e-mail: ahr@hgs.se.
} 
countries such as Canada, Finland and Sweden. Between 1991 and 1993 stumpage prices in Finland and Sweden declined by $25-40 \%$, depending on the roundwood assortment (see, e.g. Aarne, 1993). However, as is usual after a decline, the kraft price has recovered: during 1994 and 1995 it has approximately doubled. As a result, the stumpage price and forestry profitability are both climbing again. It is reasonable to assume that this cycle will be repeated in the future. Under such economic conditions forest owners have great difficulty in planning their future activities - especially their cutting levels and investments. External investors and lenders also find it difficult to plan their involvement in forestry wisely.

Theoretically, business relies on the interest theory presented in Fisher (1930) and applies the return on investment (ROI) concept based on that theory. Forestry, on the contrary, has assumed a steady-state economy and applied either forest rent or soil rent theory (see, e.g. Speidel, 1984). These theoretical foundations have been challenged in the present study, in which different approaches are considered and finally, the ROI of forestry is compared with other investments.

In Western Europe forestry accounting was being practised and bookkeeping farm networks were being implemented as early as the 1950s (Rochot, 1984). Basically, however, existing profit and loss accounts for forest owners aim at reducing taxes as much as possible. As a result, forest owners, lenders and external investors typically lack reliable information about profitability and capital returns. This problem is more serious for non-industrial private forestry than for industrial or public forestry, which are more often conducted on a large scale. Owing to the absence of generally accepted accounting principles and to changes in standing timber, different people making financial calculations about the same enterprise can come up with different results. Even making comparisons between different years for the same enterprise is difficult. Furthermore, forest valuation has been studied primarily as a separate question, without any connection with the balance sheet (see, e.g. Sagl, 1988). Forest value, however, depends on assumptions about what will happen several generations into the future (Allison, 1985). In general, the value of the standing timber can be based on the present stumpage price, sometimes called the liquidation value, land expected value or on-the-market value, all of which reflect future earning opportunities.

Controlling costs is critically important for a business manager trying to improve a firm's profitability, since it is difficult for most managers, especially for NIPF owners to influence demand and price. Unfortunately, most of them try to improve profits by expanding output rather than by reducing costs (Warren, 1983). Many forest owners try to benefit from high-season peak prices. We argue that when forest owners are aware of the actual costs involved, they will have a better basis for decisions about future investments, cutting intensities and silvicultural treatments.

The EU has encouraged accounting for agricultural holdings. In addition to the traditional Farm Accounting Network (FADN, 1989), a new project - PACIOLI (1994) - has been established for developing the accounting principles of agriculture and forestry in the FADN context (Beers, 1996).

The present study offers an alternative viewpoint for analyzing forestry profitability and the resources held by NIPF owners. It does not offer a completely new set of concepts, nor does it suggest a radical change in the forestry economy. Rather, its 
strength lies in applying existing accounting principles while also suggesting some necessary adjustments to provide a more appropriate view of the forestry property. The study will help to promote the view of forestry firms as business organizations, like any other business investment units. In our view, this is an important contribution, especially in the field of private forestry where the majority of the owner's assets grow in value and volume without this being properly reflected in the strictly regulated accounting system.

\subsection{Purpose of this study}

The key challenges addressed in this study are to develop forestry accounting theory and to evaluate different profit concepts, and to analyze the powerful fluctuations that are typical of forestry beyond the reach of regular accounting, and in order to eliminate the impact of inflation and to evaluate future opportunities.

More precisely, the purpose of the study is twofold:

(1) to propose principles for profit and loss accounts, and balance sheets for NIPF owners by applying business accounting practices and

(2) to argue for the complementing of strictly regulated accounting with contingent adjustments.

There are at present no generally accepted accounting principles for NIPF owners, hence the need to address the first point above. The second part our the purpose is necessary because the value of a forest holding depends on changes in volume, quality, assortment mix and price. This is not reflected in the profit and loss account or the balance sheet. Showing a high profit is easy with large cuttings. This does not affect the value of the forest in the balance account, even if the property is destroyed. A forest owner who invests in silviculture activities rather than cuttings may show a loss, even if the market value of the holding has increased quite substantially. Thus, to give the owner and manager of the holding a true picture of the economic result, adjustments to the realized net profit (loss) of the enterprise must be made. An economic analysis of a medium-sized forest holding is presented below, to illustrate the importance of this type of adjustment. Our analysis is based on a suggested structure for profit and loss accounts and balance sheets for NIPF owners (Hyder et al., 1994, 1996).

The general acceptance of accounting principles to give a picture of the economic situation would make for better utilization of capital and better investment decisions among NIPF owners. Why, then, sufficient effort has not been directed for developing commonly accepted means for analyzing profitability and cost for these owners? One important reason is that forestry involves a lengthy production process, which makes it difficult to calculate profit, forest value or product cost. In contrast to this, an industry-specific financial and cost accounting frame has been in general use in Finnish and Swedish mechanical engineering for roughly 20 yrs (see, e.g. Samuelson, 1989). Profitability data based on generally accepted accounting principles would provide a basis for more successful management by NIPF owners, particularly by helping them in their price negotiations and in their dealings with lenders. The key task is to support the development of a forestry- specific accounting frame, embracing 
also judgments about the future and based on the empirical studies, international references and the EU norms.

\subsection{Previous work}

The basic concepts of forestry accounting have been studied by Openshaw (1980), Frauendorfer (1987), Jöbstl (1996) and others. Attempts to tailor charts of accounts for non-industrial private forestry have been made by Lantbrukarnas Riksförbund (1989) and Kinnunen et al. (1993). Cost accounting as implemented in jointly-owned forests has been studied by Forstliche Bundesversuchsanstalt (1989), Enk (1988) and Penttinen (1992). A comprehensive recommendation for forestry accounting practice has been developed by Davy (1987).

Teränne (1993) compared the EU directives and the Finnish accounting regulations. Wurz (1993) and de Legge (1990) have described developments in costs and returns in European forestry in the 1980s. Theunisse (1994) studied the harmonization of financial reporting in the EU by comparing Belgian accounting practices with French and German. Ericsson (1996) studied accounting principles in Germany, France, Switzerland and the EU. Proposals for forestry accounting details such as product lists for cost units have been made by Eurostat (1987). A special issue, the impairment question, has been studied by Schuetze (1987) among others. The specific dilemma of property evaluation in forestry profit calculation has been described by Jöbstl (1981) and linked to forestry inventory by Jöbstl (1987b) and Hägg (1993).

\subsection{The empirical case}

With the help of an empirical case we seek to illustrate the importance to the forest owner of complementing the strictly regulated financial accounting. To a large extent the net profit (loss) of a forestry enterprise depends on the cutting volumes: large cuttings mean a high profit, while low cuttings mean a low profit or even a loss. This is balanced by the changed market value of the forest holding, especially that of the growing stock. Large cuttings mean that the standing volume is reduced. Further future cutting possibilities and increments are also affected. In a certain sense, forest may be compared with a bank account. But no adjustments are made for this change in the strictly regulated financial accounts.

Three forest management strategies, which we call extensive, balanced and intensive, will be used to illustrate the usefulness of adjusting the realized profit. The extensive strategy reflects the methods of a forest owner who is cautious about final cutting, and who maintains the level of cutting at well below a sustainable level. Private owners are said to be applying the balanced strategy if they follow the guidelines of the sustainable yield principle as regards tending and final cutting. The intensive short-run strategy is the exact opposite of the extensive model, and involves a level of cutting higher than the sustainable level. The strategies will be applied to a medium-sized NIPF enterprise in Sweden.

The forestry firm in our case has a forest area of about 75 hectares and is located in the province of Uppland, near the Stockholm region (for a more detailed description 
Table 1

Total cutting volumes 1987-1994 for the extensive, balanced and intensive total increment during the period, and standing volume at the end of 1994

\begin{tabular}{lccc}
\hline Year & \multicolumn{2}{l}{ Strategy } & \\
\cline { 2 - 4 } & Extensive & Balanced & Intensive \\
\hline 1987 & $766(666)$ & $666(666)$ & $2430(2430)$ \\
1988 & 0 & 105 & 203 \\
1989 & 178 & 178 & $489(137)$ \\
1990 & 289 & 156 & $240(240)$ \\
1991 & 0 & 258 & 452 \\
1992 & 470 & 42 & 0 \\
1993 & 0 & $1001(957)$ & $3092(3092)$ \\
1994 & 412 & 253 & 583 \\
Sum & $2115(666)$ & $2659(1623)$ & $7489(5999)$ \\
Total increment & 2436 & 2437 & 2115 \\
Standing volume & & & 4268 \\
$(31.12 .94)$ & 9964 & 9221 & \\
\hline
\end{tabular}

of the case and its background, see Hyder \& Lönnstedt, 1993). Site productivity is $6.3 \mathrm{~m}^{3} \mathrm{sk} / \mathrm{ha}$, while the volume, calculated at the end of 1991 , approaches $129 \mathrm{~m}^{3} \mathrm{sk} / \mathrm{ha}$ - slightly lower than the provincial average. More than one-third of the area is covered by older forest, and is therefore ready for final cutting. About $17 \%$ of the forest is suitable for thinning; the remainder comprises young trees. The forest area is dominated by pine (about $60 \%$ ). One-third of the total area contains spruce.

The standing volume at 1 January 1987 is $9643 \mathrm{~m}^{3} \mathrm{~s}$. As can be seen from Table 1, the total cut volume varies quite substantially between the three strategies, especially if the intensive strategy is compared with the other two. As a result, the standing volumes at the end of 1994 are also quite different.

\section{Outline of principles for forestry accounting}

\subsection{Basics of forestry accounting}

Accounting is based on postulates, theoretical concepts and principles (see, e.g. Belkaoui, 1985). These general principles and rules are applied here in order to guarantee a solid economic basis. Ideally, the forestry entity should be separate and distinct from the owner's other entities, e.g. agriculture. In practice, however, these different entities might form one enterprise, e.g. an agroforestry enterprise (see, e.g. the evaluation of the economics of agroforestry in Thomas, 1991). The owners and lenders of a concern assume that the entity is not expected to go into liquidation in the foreseeable future, and this holds for sustainable forestry. The unit-of-measure postulate assumes that accounting is limited to the production of information in 
monetary terms. In forestry, accounting typically also includes the volumes needed for profitability and productivity. The accounting-period postulate assumes a fixed reporting period, typically one fiscal year.

The American Accounting Association (1977) defines the classic approach, which constructs implicit accounting models for common use — as does the present study. The classic approach embraces two sub-approaches: (i) The deductive, which focuses on differences in wealth between two points in time and (ii) the inductive which emphasizes realized values during the accounting period and the profit and loss account (Lukka (1989), cf. also Belkaoui (1985)). According to this model, the accounting procedure of a forestry enterprise will — as in any other business, will comprise at least a profit and loss account and a balance sheet, as well as cost accounting. Some attempts have been made to calculate the cost of producing one cubic meter of different roundwood qualities (Mann, 1986).

\subsection{Profit and loss accounts for external use}

When calculating the profit or loss for a forestry firm, as for any business, it is necessary to calculate realized revenues. The revenue principle specifies the nature, the measurement and the timing of revenue. The revenue is measured as the net cash equivalent excluding miscellaneous taxes, such as sales tax. Revenue can be calculated according to the accrual method when the price of the product is known with certainty and the goods have been sold.

Important sources of revenues in forestry consist of the sale of timber and other forest products, and the value of the forest products used for the repair, maintenance and construction of the forest enterprise. Formally, products used outside the enterprise, e.g. in agriculture, or for the owner's private consumption, belong to production for own use (Teränne, 1993). Revenues are also obtained from hiring out the estate for hunting; a monetary evaluation for this has been developed for the USDA Forest Service by Loomis (1989). For the value of forest products used for the repair, maintenance and construction of the forest enterprise, "silent acknowledgment" is adopted. The forest owner can hunt, but it is usually difficult to assess the value of the benefit. If accounting rules are followed, state allowances to the forest enterprise should be recognized as extra ordinary items after operating profit. In practice, however, they are often regarded as revenues.

Our suggestion for profit and loss accounting for forestry is shown in Fig. 1. The proposal has been applied and tailored for forestry according to the new Accounting Act and Accounting Ordinance, which has been modified according to the article 9 of the 4th EU directive (Teränne, 1993). Net profit derives mainly from sales of wood from final cutting and thinning during the accounting period.

A comment is necessary about the direct silvicultural costs associated with the maintenance of the forestry firm and the development of the forest. Since the effects of silvicultural treatments are difficult to measure, and since they typically occur after the fiscal year in which the respective final cuttings take place, costs for these treatments are not subsumed under the direct logging costs in the previous step. However, an estimated amount of silvicultural cost is charged to the 
PROFIT AND LOSS ACCOUNT FOR EXTERNAL USE

\begin{tabular}{|c|c|c|}
\hline & 1994 & 1993 \\
\hline Net turnover & 119 & 643 \\
\hline Variable costs (e.g.direct logging costs) (-) & 35 & 127 \\
\hline Gross Margin & 84 & 516 \\
\hline Direct silvicultural costs (-) & 0 & 66 \\
\hline Margin after variable costs & 84 & 450 \\
\hline Fixed costs e.g. overhead forestry costs and expenses (-) & 35 & 34 \\
\hline Operating Margin & 49 & 416 \\
\hline Depreciation (-) & 4 & 4 \\
\hline Operating profit (loss) & 45 & 412 \\
\hline \multicolumn{3}{|l|}{ Financial income and expenses } \\
\hline Interest income $(+)$ & 20 & 18 \\
\hline Interest expenses (-) & 5 & 8 \\
\hline Net profit (loss) of the enterprise & 60 & 422 \\
\hline
\end{tabular}

Fig. 1. Proposal for a profit and loss account for external use in USD per hectare for the financial years 1993-1994 when a sustainable production, here called the balanced strategy, is applied (1 USD = 7.1 SEK).

result of the financial year as a kind of operational reserve, here referred to as silvicultural liabilities, so that the calculation does not show inflated income. However, in the next few years when silvicultural treatments are carried out, this cost will be paid. As long as the cost is not paid it is a liability for the enterprise and is shown in the balance sheet.

\subsection{Profit and loss account for private use}

In our view a calculation of realized revenues is not sufficiently informative. NIPF owners do not necessarily realize revenues by way of roundwood sales each year, although the growth of the standing forest does generate unrealized revenues. Thus, the narrow view of revenue excludes investment income and gains and losses on the disposal of fixed assets. The value of the property may change because of changes in (i) volume, (ii) quality and/or (iii) the price of the timber, which neither generate business transactions nor leave any trace in the accounting. Changes in the value of the 
growing stock have to be considered, if changes in current assets are to be calculated realistically. Support for this view can be found in the capital impairment rule (see, e.g. Schuetze, 1987), which recognizes changes in property values as part of profit or loss. The capital impairment rule states that revenue contributes to the increase in the net assets, which is the difference between the assets and liabilities of the firm. We apply the rule here by including the growing stock as part of the current assets, and charge changes in this stock to a revaluation reserve. Note that the reserve is not available for distribution until realized (Davy, 1987).

Ashby and Funk (1980) argue that failure to measure the unrealized values should be regarded as a deviation from accounting principles. In order to design a true profit and loss account, it is necessary to undertake a capital valuation of the woodlands (Openshaw, 1980). The inclusion of the capital valuation leads to the evaluation of a calculated profit for the property, which completes the result provided by the financial accounting. The calculated profit is the best possible estimate of the net result of the forest enterprise, which can be compared with the results of other forest enterprises or investments. If changes in the value of the growing stock are ignored, measures of profit and return may be misleading, as Penttinen and Uotila (1996) have shown.

The unrealized revenues/losses are caused by the difference between the current value of the forest and that of the previous year. In all, the central instruments for measuring the net result of forestry are (i) the accounting and (ii) the forest survey, which is a detailed study of forest stands (for a combination of forest survey and accounting see, e.g. Jöbstl, 1987b). It can be noted that sustainability, which limits the exploitation of growing stock, has recently been emphasized and defined more precisely (The Ministry of Agriculture and Forestry, 1995) and has also been included in innovative accounting techniques of Finnish corporations (Niskala, 1995).

In Finland and Sweden, the NIPF owners produce their surveys and forest management plans every tenth year. The information on growing stock can be obtained from the management plans (see, e.g. Jöbstl, 1987a). Between surveys, the difference between the actual and the permissible cut can be used together with price and cost information, to calculate the timber balance. The change in the value of the forest holding affects the profit calculations. A simplified method involved using the growing stock (forest inventory) and standardized prices and costs (Jöbstl, 1981). Alternatively, the market prices for roundwood can be used in evaluating growing stock. Changes in the market price of the forest land can also lend precision to the evaluation.

Here, the so-called capital impairment rule is applied to the growing stock. This means that roundwood price and changes in the volume of growing stock are included both in the changes in forest value in the profit and loss statement, and in the closing valuation of the forest in the calculated balance sheet. The value of the forest land is calculated by means of a valuation method developed by the authority of Land Survey (see Hyder \& Lönnstedt, 1993). The method takes into account the change in the state of the forest, including volume and site productivity. These factors are used to calculate the market value of the forest. Since the market value can change 
dramatically, we have used an average of the market price over the last five years. This procedure emphasizes the fact that the forest is a long-term investment, and mitigates the effects of abnormal fluctuations in market prices.

In adjusting the net profit (or loss) to obtain the calculated profit (or loss), it is necessary to adjust not only for changes in the forest value, but also for net interests and the cost of work by the owner, in order to provide a profit that can be used in comparisons with other alternative investments. The effect of the net interest, i.e. the difference between interest income and interest expense, is eliminated because NIPF ownership involves a variety of financial situations. Their amount of loans for instance, will vary significantly. If interest is included, it will be difficult to make comparisons between the forest enterprises because differences between NIPF owners could be related to such factors as the consumption habits of the individuals concerned rather than to the forest enterprises themselves. A cost adjustment is also necessary if the individual owners work in the forest themselves. Determining this adjustment has been the most difficult problem in implementing a countrywide forestry book-keeping network (for an example of an implemented network, see Sekot, 1990). Note that wood can be used either (i) inside the forest enterprise (e.g. for the construction of buildings) or (ii) outside it (e.g. as firewood by the owner privately). Theoretically, internal use comes under the heading of material and supplies (i.e. variable costs). In practice, what is known as silent acknowledgment is applied, i.e. the transaction is ignored. External use, on the other hand, is part of revenue. In the same way, all consumption (such as the value of the owner's own hunting privileges) should be considered as revenue, if it is evaluated according to strict accounting methods (Penttinen, 1992; Loomis, 1989). Our proposal for a private profit and loss account for forestry is shown in Fig. 2.

PROFIT AND LOSS ACCOUNT FOR PRIVATE USE

\begin{tabular}{lrr}
\hline & 1994 & 1993 \\
\hline Net profit (loss) of the enterprise & 60 & 422 \\
& 15 & 10 \\
Adjustment of net interest $( \pm)$ & 111 & 109 \\
Change in forest value $( \pm)$ & 0 & 0 \\
Compensation for own work (-) & 156 & 521 \\
\hline Calculated profit (loss) of the enterprise & & \\
\hline
\end{tabular}

Fig. 2. Proposal for a profit and loss account for private use in USD per hectare for the financial years 1993-1994 when a sustainable production, here called the balanced strategy, is applied (1 USD = 7.1 SEK). 


\subsection{Balance sheet for external use}

The balance sheet shows a consolidated statement of the assets and liabilities of the enterprise at the end of the year, and constitutes a focal point for the start of the next (Theophilus, 1982). Fig. 3 shows a proposed balance sheet format for forestry according to the new Accounting Act and Accounting Ordinance, which apply article 9 of the 4th EC directive (Teränne, 1993).

BALANCE SHEET FOR EXTERNAL USE

\begin{tabular}{|c|c|c|}
\hline ASSETS & 1994 & 1993 \\
\hline \multirow{2}{*}{\multicolumn{3}{|c|}{$\begin{array}{l}\text { FIXED ASSETS AND OTHER NON-CURRENT } \\
\text { INVESTMENTS }\end{array}$}} \\
\hline Tangible assets & & \\
\hline Purchase value & 916 & 916 \\
\hline $\begin{array}{l}\text { Machinery and equipment } \\
\text { Forest roads }\end{array}$ & 106 & 111 \\
\hline \multicolumn{3}{|l|}{ Financial assets } \\
\hline Forestry account & 140 & 130 \\
\hline \multicolumn{3}{|l|}{ CURRENT ASSETS } \\
\hline \multirow{3}{*}{$\begin{array}{l}\text { cash on hand and banks } \\
\text { (cash, bank balance, etc.) }\end{array}$} & & \\
\hline & 101 & 94 \\
\hline & 1263 & 1251 \\
\hline LIABILITIES & 1994 & 1993 \\
\hline \multicolumn{3}{|l|}{ CAPITAL AND RESERVES } \\
\hline Equity capital & 900 & 553 \\
\hline \multicolumn{3}{|l|}{ Retained earnings/surplus } \\
\hline Untaxed reserve & 140 & 130 \\
\hline Net profit of the enterprize & 60 & 422 \\
\hline \multicolumn{3}{|l|}{ CREDITORS } \\
\hline \multicolumn{3}{|l|}{ Non-current } \\
\hline $\begin{array}{l}\text { Silvicultural liabilities and long-term bank loans } \\
\text { Current }\end{array}$ & 84 & 66 \\
\hline \multirow[t]{2}{*}{ Short-term loans from credit institutions and others } & 79 & 80 \\
\hline & 1263 & 1251 \\
\hline
\end{tabular}

Fig. 3. Proposal for balance sheet for external use in USD per hectare for the financial years 1993-1994 under a balanced strategy, of sustainable production. 
Assets are displayed first, followed by liabilities, in accordance with conventional practice. In compliance with the EC directives, assets are grouped so that the least liquid funds come at the beginning, and the most liquid funds at the end. (In Sweden, the traditional order has been the reverse.) Fixed assets such as machines, forest roads, etc. have their depreciated values included under assets. However, for most forest owners the capital tied up in machinery and other equipment is limited.

The grouping of liabilities and equity follows the same pattern as for the assets. Short-term liabilities are those payable within one year. Long-term liabilities due within one year are the current portions of long-term loans, and according to the 4th EC directive these must be shown separately under current creditors (Teränne, 1993). According to the EC directives, a distinction is made not between short-term and long-term liabilities, but between loans and allocations. Long-term liabilities in forestry include mainly state and bank loans, as well as silvicultural liabilities, which are a reserve, and arise as a consequence of final cuttings. These silvicultural treatments are compulsory in Finland and Sweden but, as noted, are not carried out during the year of the final cutting. However, the costs of these treatments are duly charged to the profit and loss account for the financial year, to show a justified profit. The amount of the cost is a liability for the forest enterprise, since the cost is not paid until the silvicultural treatment is carried out. This liability will disappear with the payment of the cost, and the profit and loss account is then adjusted by the difference between the actual cost and the reserve.

\subsection{Balance sheet for private use}

The closing value of the forest is the most significant item in the assets of a NIPF owner, and is calculated at the end of the financial year. Different calculating methods have been developed; see for example Airaksinen (1989), Sagl (1988) and Hyder and Lönnstedt (1993). For private use it is important for owners to adjust the value of the forest holding and their own equity capital in the private balance sheet. Using the method of the Swedish land survey (Hyder \& Lönnstedt, 1993), we have calculated the closing value of the forest under three different strategies. In all three cases the evaluation is based on the best local know-how, using five-year moving averages for each fiscal year.

\section{Comparing economic results}

Our calculations show that the result, measured as net profit, is not satisfactory when the extensive or balanced strategies are applied (Fig. 4). This is because the level of cutting, except for the balanced strategy in 1993, is either low or nil. Thus it is difficult for the firm to cover its running costs. In the case of the extensive strategy, there was no sale of wood in 1988, 1991 or 1993, which means that the firm had to find extra resources to pay its expenses during those years. Costs consist of forestry costs and expenses, depreciation and negative net interest. Depreciation does not really require any payment, but other costs must be paid. If the firm cannot generate funds 


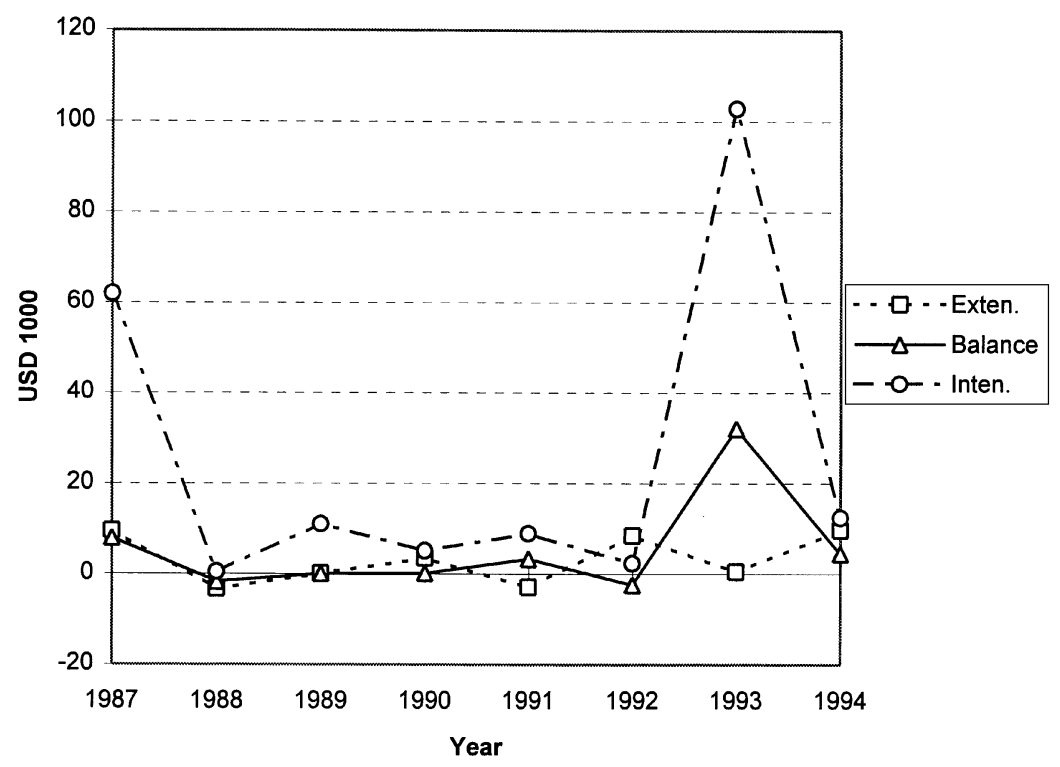

Fig. 4. Net profit under three different strategies (in 1000 USD).

from the sale of wood, these costs are covered from reserves or by the forest owner personally.

Fig. 5 compares the calculated profit under the three different strategies. The change in the value of forest is added to the net profit to obtain the calculated profit. As is evident (from the application of the intensive strategy), a high net profit for one year can be balanced by a negative change in the forest value (compare Fig. 4 with Fig. 5). To ensure comfortable growth in the forest in all the years, an owner must be careful about the volume of cutting that generates net profit. Except for 1987, 1993 and 1994, which were extreme years with respect to cutting, the calculated profit shows a moderate difference between the strategies.

The value of the forest constitutes most of the forestry firm's total assets. In forestry, long-term loans are often taken out to finance the purchase of the estate or of machines. In calculating profitability it is important to observe the growth of equity capital. As is well known, the share of equity capital in private forestry is usually high. Fig. 6 shows the growth of equity capital under the three strategies. Owing to a gradual rise in the price of wood and in inflation, the curves show fairly uniform growth in equity capital over the period. The extensive and balanced strategies differ greatly from the intensive strategy. When the intensive strategy is applied, the equity capital for 1987 and 1993 shows a sharp decrease as a consequence of large final cuttings. To some extent this can also be seen under the balanced strategy in 1993 .

We have also compared the calculated return on investments under the three different strategies (Fig. 7). The intensive strategy shows the highest return in 1987 and 1993 and the lowest in 1988 and 1994. In fact it was the high return in 1987 and 1993 


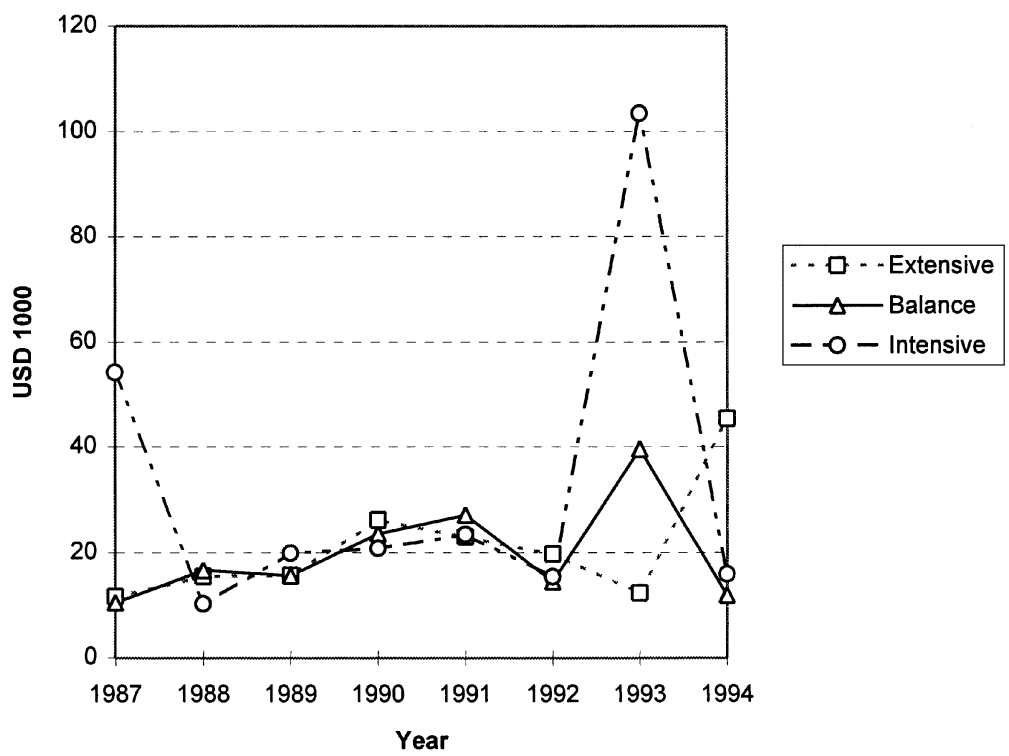

Fig. 5. Calculated profit under three different strategies (in 1000 USD).

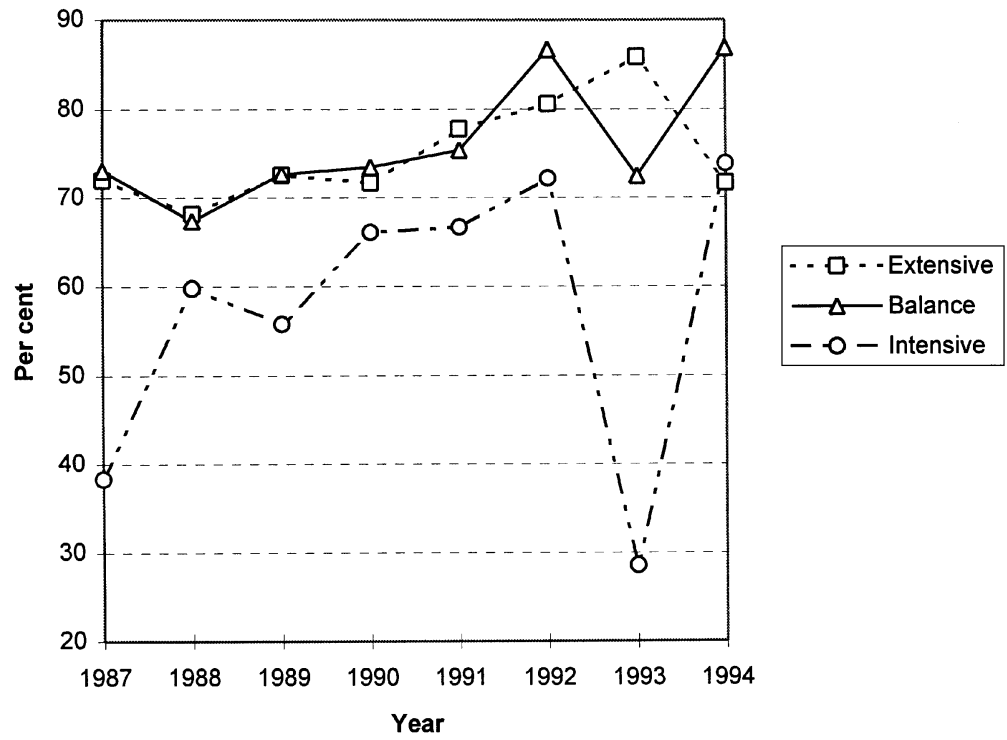

Fig. 6. Equity to total capital ratio under three different strategies.

which caused the low result the following year. The same effect can be seen in 1993 and 1994 under the balanced strategy. Under all three strategies it is worth noting the drop in calculated return on investments during the period 1990-1992. The cause was a fall in timber prices due to a weak market for forest industrial products. 


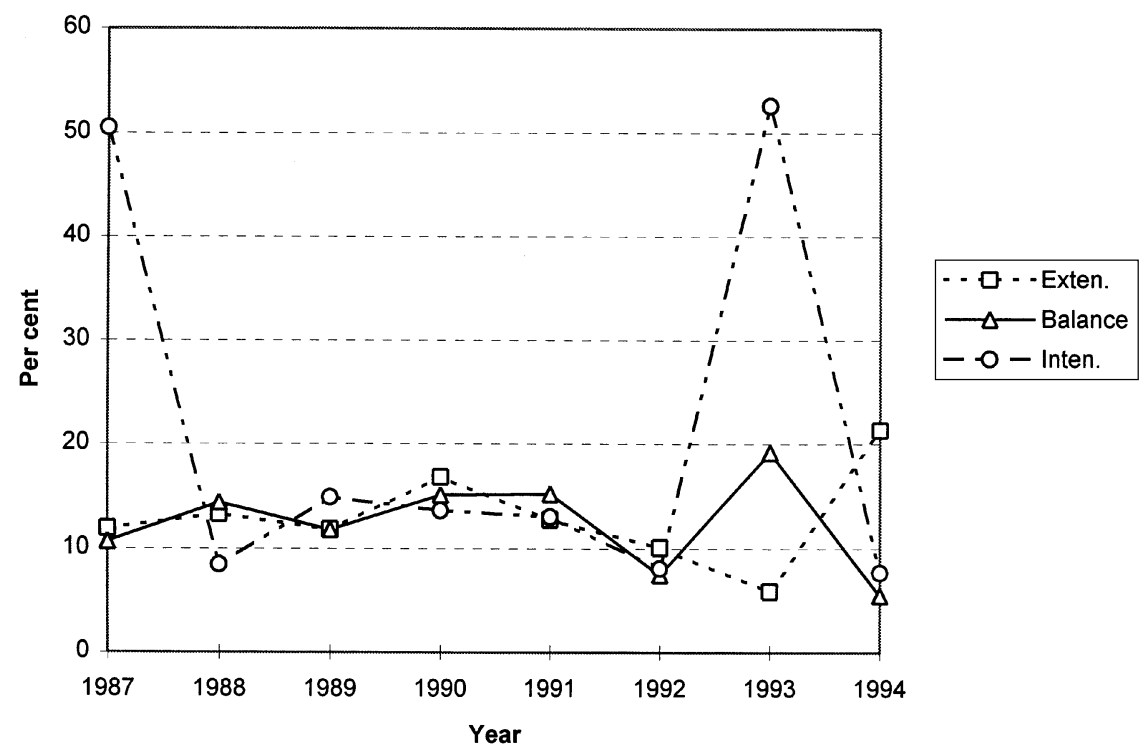

Fig. 7. Calculated return on investments (ROI) under three different strategies.

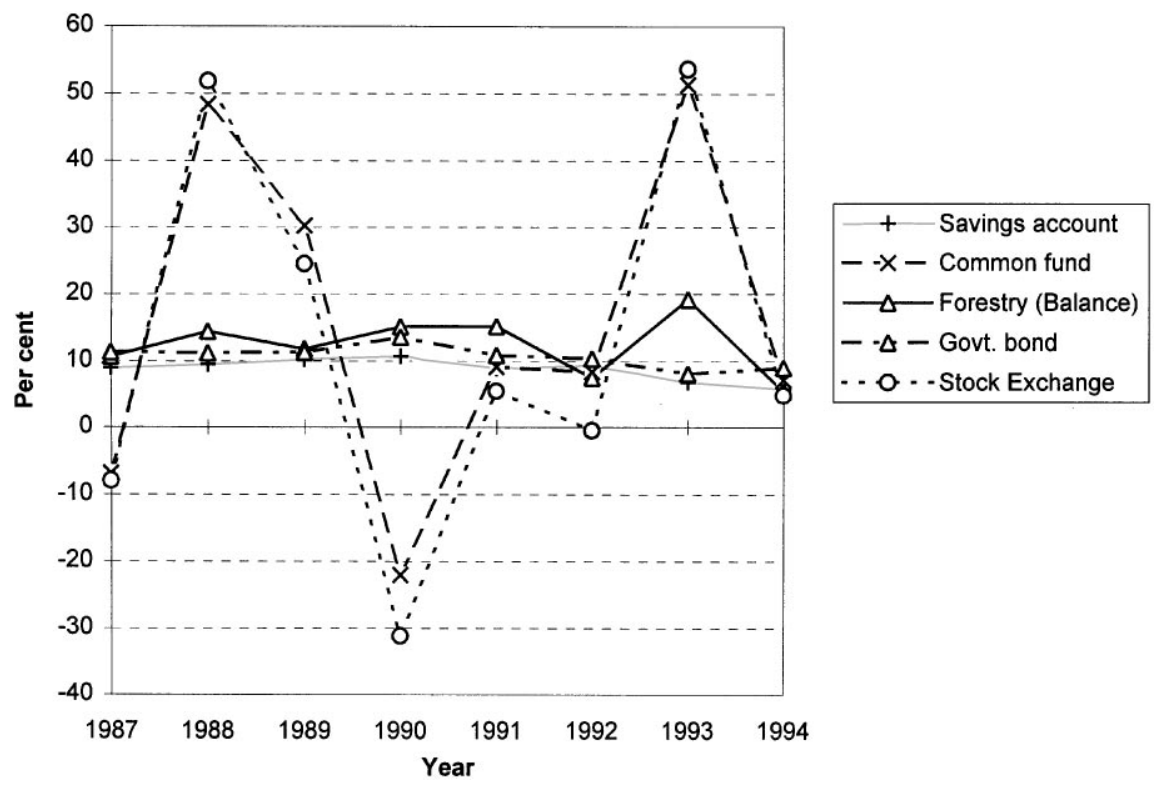

Fig. 8. Return on Investment (ROI) of forest property compared with other investment opportunities. 
It is interesting to compare forestry profitability with other kinds of investment (see, for example, Baardsen \& Eid, 1991). For this comparison we have used the forestry firm's calculated return, which includes both revenues from cuttings and unrealized revenues. Since the balanced strategy reflects the commonly adopted sustainable-yield principle, we use the return for this strategy as a yardstick for the comparisons. The main alternative investment possibilities that might be interesting as a comparison are government bonds, stocks and bank savings. It is clear from Fig. 8 that government bonds yield a stable and high return in the financial markets. During the period studied, stocks yielded the most uncertain return. The figure shows that for the eight years covered, forestry offers a better average return than government bonds and saving accounts for the eight years. This result is in conformity with the findings in Kula (1988), where it was found that forestry investment was superior to bank savings in Northern Ireland. However, it is important to remember that the data presented are based on few cases only.

\section{Management implications}

This study recognizes two important but conflicting facts - a forestry firm, like any other business firm, is an interesting investment object. At the same time it differs markedly from other business entities in many ways, such as rotation time and valuation of the property. A NIPF owner thus needs to understand these facts, and to act in such a way that the forestry firm can be managed more economically and profitably.

In this study we have stressed the cost of production, which has a direct impact on the profitability of the firm. A NIPF owner must be aware of the sources of cost in order to organize better and to increase profit margins in forestry. A NIPF owner who sees the forest land in a specifically commercial light, should maintain records of the costs of operation. It is important to see a forestry undertaking as completely separate from any other activities, so that only costs directly related to the forestry business should be included in this accounting. If the same machinery or equipment is used for other purposes (as is usually the case), the NIPF owner needs to be sure that the forestry firm is duly charged for the cost, no more and no less. A cost accounting system for forestry has been developed by Penttinen et al. (1995) on the basis of some 61 test forest holdings.

An interesting aspect of forestry accounting concerns the part of the costs relating to the final cutting. Costs of cleaning and planting are generated by the final cutting, but are not incurred in the same year. We therefore recommend that NIPF owners properly periodize these costs, so that income does not appear inflated. It is a practical convenience to reserve funds from the final cutting for the silvicultural treatments that must follow, usually within a period of three years. Detailed cost information is essential to any proper and satisfactory profitability study of a forestry firm. But how detailed the cost information should be will depend partly on the ambition of the owner, and partly on the size of the firm. To reap real benefits from the systematic accounting which we have proposed, a forestry firm should be at least medium-sized. 
We recommended that, in addition to the external financial accounts, the NIPF owner should keep private financial accounts. Two types of return should be presented - realized net profit and calculated profit. The external financial accounts should be based on accepted accounting theory, while the private financial accounts should be based on concepts reflecting the peculiar reality of forest holdings. But we recognize that calculating two types of profit may be confusing or even undesirable. This poses a dilemma for forestry: on the one hand, calculated profit is not a profit which can be seen or immediately used; on the other hand, the net profit - which is the operational profit for a particular period - does not reflect the true activity of the firm. We therefore recommend that the NIPF owner should pursue both kinds of profit, each in relation to its own objective. The net profit is mainly useful for official purposes such as taxation, and for financially related affairs such as cash payment and assessments of the financial position. The calculated profit is more valuable for internal purposes, for instance in managing the firm in a more professional way, and in dealing with the financial institutions and prospective buyers. If a NIPF owner shows only the net profit, a bank manager may make a mistaken estimate of the firm. Although the calculated profit is not yet realized, a substantial part can be realized at reasonably short notice. In our view, the NIPF owner must emphasize the calculated profit in dealing with the banks. A net profit in a forestry firm applies to a particular and rather limited time, while the calculated profit stretches over a longer period. Accordingly we suggest that bank authorities dealing regularly with forestry firms should pay greater attention to the calculated profit to get a clearer picture of the firm.

In this study we have applied three alternative management strategies, as defined by the level of cutting. It is not our view that once the individual NIPF owner has adopted a certain strategy, this must continue to be used even if it is no longer suitable for the firm in question. NIPF owners know their firms best, so they should be free to choose any of the strategies and at any time. What strategy is best at a particular time will depend largely on the prevailing financial conditions, the state of the forestry firm and, finally, the NIPF owner's access to vital information and ability to make the right decisions.

\section{Conclusions}

The economic performance of a forest enterprise depends mainly on the way revenues, costs and expenses are calculated. The net profit of a private enterprise shown in the external profit and loss account includes realized revenues and costs, while the calculated profit of the property shown in the private profit and loss account, which can be compared with other forest holdings and investments, also includes non-realized items such as the growth in the value of the standing timber. Both the realized and calculated profit give important information. The realized profit, which mainly depends on cutting and silvicultural treatments, represents activities in the financial year and their actual result. It provides the forest owner with a good overview of the financial transactions and their economic result. However, the picture provided by the net profit is incomplete and, in some situations, misleading. 
One large final cutting which yields a high net profit, could reduce future profits. The net profit cannot be used for comparing results with other activities and businesses. The calculated profit is computed for this purpose. However, as our case study has shown, even a positive calculated profit can conceal a real financial problem. The forestry enterprise may lack realized revenues and consequently, liquidity. These two measures of profit thus have to be treated separately in order to avoid complications and misunderstandings. The realized and calculated profit, and the relationship between them, allow the forest owner to assess the relative benefit of cuttings and developing the volume and value of the firm, in the spirit of multiple-criteria decision making.

We claim that the proposed differentiation between accounting for external and private use can have implications for policy-making at three levels. Associations of NIPF owners could recommend that their members maintain both types of accounting for different purposes, as suggested here. Financial organizations which lend to private forestry enterprises, could start asking for both types of accounting. This sort of combined information provides a more realistic view of the forestry firm and hence a sounder basis for decision making. Finally, the suggested practice supports the harmonization policy for forestry accounting in the EU since it has been developed in the spirit of forestry accounting studies in other European countries and in the light of the experience acquired there.

We recommend that future research should develop a simple valuation method. This is an absolute prerequisite for the successful implementation of cost accounting among NIPF owners. Given the variations in cutting volumes, the method must allow for changes in the value of the woodland due to changes in volume, quality and prices. Otherwise it is all too easy to present misleading results and to show a meaningless rate of return. Further, a more general economic analysis of the profitability of Swedish non-industrial private forestry is needed. Profitability ought to be compared with profitability in other countries, as well as with other investments. A network of nationwide bookkeeping for forest holdings could generate a basic data set for economic analysis, providing a cornerstone for price negotiations between NIPF owners and the industry.

\section{References}

Aarne, M. (Ed.) (1993). Yearbook of forest statistics. Helsinki: The Finnish Forest Research Institute.

Airaksinen, M., (1989). The current price of a share of a jointly-owned forest. Helsinki: National Board of Survey, Publication 64. (in Finnish).

Allison, B. J. (1985). Forests as money. New Zealand Journal of Forestry, 30, 267-277.

The American Accounting Association (1977). Statement on accounting theory and theory acceptance, American Accounting Association.

Ashby, R. W., \& Funk, G. D. (1980). Accounting for contract costs and value in the forest products industry. Management Accounting, 58, 41-44.

Baardsen, S., \& Eid, J. (1991). Profitability in forestry and in some other selected sectors based on the national accounts in Norway, Scandinavian Forest Economics, 33, 113-127. 
Beers, G., Poppe, K. J., \& Pruis H. C. (Eds.) (1996). PACIOLI 2, Accounting and managing innovation. The Hague: Agricultural Economics Research Institute, Mededeling 534, Workshop Report.

Belkaoui, A. (1985). Accounting theory. 2nd edn. San Diego: Harcourt Brace Janovich.

Boss, D., Burri, R., Echsle, A., Flachsmann, B., Göderle, J., Hollinger, G., \& Schickmüller, R. (1996). Betriebsabrechnung Grundlagen-Handbuch. Zürich.

Davy, A. R. (1987). Accounting of forestry activities in New Zealand. Research Bulletin R-117. Wellington: New Zealand Society of Accountants.

Enk, H. (1998). 10 Jahre Kostenuntersuchung bei Tiroler Agrargemeinschaften und Gemeindewäldern. Vienna: Forstliche Bundesversuchsanstalt.

Ericsson, L. (1996). Accounting principles in Germany, France, Switzerland and the EU (Redovisningsprinciper i Tyskland, Frankrike, Scweiz samt EU). Uppsala: Department of Forest Economics, Swedish University of Agricultural Sciences, Report 229.

Eurostat (1987). Manual of economic accounting for agriculture and forestry. Luxembourg: Office for Official Publications of the European Communities.

FADN (1989). Farm accountancy data network. An A to $Z$ of methodology. Luxembourg: Commission of the European Communities.

Fisher, I. (1930). Interest theory. New York: MacMillan.

Forstliche Bundesversuchsanstalt (1989). Anleitung zur Kosten-Ertragsuntersuchung in Agrargemeinschaften und Gemeindewäldern. Vienna.

Frauendorfer, R. (1987). Betriebswirtschaftslehre für Forstwirte. Vienna: Universität für Bodenkultur, Institut für forstliche Betriebswirtschaft und Forstpolitik.

Hyder, S. A. and Lönnstedt, L. (1993). Ekonomisk resultatsredovisning för privatskogsbruket - förslag och exempel. Accounting for nonindustrial private forest owners - A proposal and case study. Department of Forest-Industry-Market Studies. Uppsala: The Swedish University of Agricultural Sciences, Report No. 29 .

Hyder, S. A., Lönnstedt, L., \& Penttinen, M. (1994). Outline of accounting for nonindustrial private woodlots. Silva Fennica, 28, 15-137.

Hyder, A. S., Lönnstedt, L., \& Penttinen, M. (1996). Economic analysis of nonindustrial private forestry. An example based on suggested accounting principles. Mitteilungen der Forstlichen Versuchs- und Forschungsanstalt Baden Württemberg, 195, 52-72.

Hägg, A. (1993). A model for determining the change in value of the forest capital during the financial year. Umeå: Department of Forest Products, Swedish University of Agricultural Sciences, Report 240.

Jöbstl, H. (1981). Zum problem der vermögensveränderungen in der forstlichen erfolgsrechnung. Allgemeine Forstzeitung, 92, 411-412.

Jöbstl, H. (1987a). Gesamtkonzeption für den einsatz im rechnungswesen. Österreichische Forstzeitung, 98, $6-11$.

Jöbstl, H. (1987b). Mittelfristige erfolgsanalyse des forstwirtschaftsbetriebes auf der grundlage der forsteinrichtungsinventur und der vollzugnachweise. Allgemeine Forstzeitschrift, 42, 433-436.

Jöbstl, H. (1996). Rechnungswesen in der Forst-und Holzwirtschaft. Band II, erweiterte und völlig neugestaltete Auflage FOWI Berichte, Ableilung fur Rechnungswesen und forstliche Marktlehre Wien, Österreichischer Agrarverlag. Wien, Heft, 9, p. 83.

Kinnunen, M., Hakkarainen, J. Hyttinen, P., Penttinen, M., \& Valkonen, J. (1993). Profitability of nonindustrial private forestry - Accounting and ratio analysis. Joensuu: Faculty of Forestry, University of Joensuu. (in Finnish).

Kula, E. (1988). A profitability analysis for private sector afforestation projects in Northern Ireland. Irish Banking Review, 32, 33-41.

Lantbrukarnas Riksförbund (LRF) (1989). Baskontoplan Nr 12200: Skogsbruk. Allmänningar. Uppsala: Lantbrukarnas Riksförbund. (in Swedish).

de Legge, R. (1990). L'investissement forestier en Europe. Analyse Financière, 80, 15-17.

Loomis, J. B. (1989). A more complete accounting of costs and benefits from timber sales. Journal of Forestry, 87, 19-23.

Lukka, K. (1989). An ontological analysis of accounting concepts. Example: in what sense does accounting profit exist? (in Finnish, summary in English). The Finnish Journal of Business Economics, 38, 94-116. 
Mann, H. J. (1986). Reinertrag und Rentabilität im Privatforstbetrieb. Was kostet ein Wald und was bleibt im Privatwald unterm Strich. Holz-Zentralblatt, 12, 516-521.

The Ministry of Agriculture and Forestry 1(995). Criteria and indicators of sustainable forestry of Finland. Interim project report. Helsinki: Department of Forestry. The Ministry of Agriculture and Forestry. (in Finnish).

Niskala, M. (1995). Accounting and sustainability — how Finnish transnational corporations are responding to the demands of sustainable development: a comparison of Finnish and international data. Finland: Department of Business Administration, University of Lapland.

Openshaw, K. (1980). Cost and financial accounting in forestry: a practical manual. Oxford: Pergamon Press.

PACIOLI (1994). Panel in Accounting for Innovation. Offering a Lead-up to the use of Information modelling. Commission of the European Communities Directorate-General for Agriculture DG VI.F.II, Concerted Action Technical Annex, Contract. No. AIR 3 CT9.

Penttinen, M. J. (1989) Accounting and business planning in a forest enterprise. Scandinavian Forest Economics, 31, 1-35

Penttinen, M. (1992). J., Applicability of profit and cost accounting models to jointly-owned forests. in Finnish, Summary in English. Folia Forestalia, 799, 1-60.

Penttinen, M., Aarnio, J., Uotila, E., \& Valkonen, J. (1995). Cost accounting in nonindustrial private forestry. TTS Institute, Report 2, 36, (in Finnish).

Penttinen, M., \& Uotila, E. (1996). Implementing management accounting to nonindustrial private forest enterprise. Mitteilungen der Forstlichen Versuchs- und Forschungsanstalt Baden Württemberg, in press.

Rochot, A. (1984) La comptabilité forestière dans huit Pays de l'Europe de l'Ouest. Nancy: INRA, Laboratoire d'Economie Forestière.

Sagl, W. (1988). Waldbewertung. Vienna: Universität für Bodenkultur, Institut für forstliche Betriebswirtschaft und Forstwirtschaftspolitik.

Sagl, W. (1994). Betriebsanalyse-eine Einführung in die Aufgaben und methodischen Grundlagen. Centralblatt für das gesamte Forstwesen, 111, 109-127.

Samuelson, L. (1989). The development of models of accounting information systems in Sweden. Scandinavian Journal of Management, 5, 293-310.

Schuetze, W. (1987). Disclosure and the impairment question. Journal of Accountancy, 164, $26-32$.

Seiler, A., Glanzmann, G., Boissonnas, G., \& Echsle, A., Projekt FIS. (1992). Schlussbericht. Aufbau eines Forstökonomischen Informationssystems erfordert umfassende Anstrengungen. Zürich: ETH Zürich.

Sekot, W. (1990). Fostliche Testbetriebsnetze. Schriftenreihe des Instituts für forstliche Betriebswirtschaft und Forstwirtschaftspolitik. Vienna: Band 9, Universität für Bodenkultur.

Sekot, W. (1994). Die forstliche Betriebsarbrecknung im Rahmen von Testbetriebsnetzen. Centralblatt für das gesamte Forstwesen, 111, 143-164.

Speidel, G. (1994). Forstliche Betriebwritschaftslehre. Hamburg: 2Auflage, Verlag Paul Peray.

Teränne, P. (1993) Comparison between the present Finnish accounting regulations and the 4th and 7 th EC directives. Brussels: Commission of the European Communities, Directorate General, Internal Market and Financial Services, Company law and accounting standards.

Theophilus, T. W. D. (1982). A new look at the balance sheet. Farm Management, 4, 355-361.

Theunisse, H. (1994). Financial Reporting in EC countries. Theoretical versus practical harmonization: two case studies. European Accounting Review, 1, 143-162.

Thomas, T. (1991). A spreadsheet approach to the evaluation of the economics of temperate agroforestry. Forest Ecology and Management: Special Issue on Agroforestry, 45, 1-4.

Warren, M. (1983). Profitable cost reduction and control, Farm Management, 5, 89-93.

Wurz, R. (1992). The development of the costs and returns in European forestry 1980-1990. Vienna: Präsidentenkonferenz der Landwirtschaftskammern Österreichs.

Wurz, R. (1993). Die entwicklung der kosten und ertäge in forstbetrieben europas 1980 bis 1990 . Österreichische Forstzeitung, 104, 37-39. 